\title{
Aktivitas antibakteri ekstrak etanolik kulit batang jambu mete (Anacardium occidentale Linn.) terhadap Staphylococcus aureus
}

\author{
H. Harsini \\ Departemen IImu Biomaterial Kedokteran Gigi, Fakultas Kedokteran Gigi, Universitas Gadjah Mada, Yogyakarta, Indonesia \\ JI Denta No 1, Sekip Utara, Yogyakarta, Indonesia; e-mail: harsiniugm@yahoo.com
}

Submisi: 29 Desember 2016; Penerimaan: 24 Oktober 2017; Publikasi online: 29 Desember 2017

\begin{abstract}
ABSTRAK
Aktivitas antibakteri merupakan tanda terganggunya pertumbuhan bakteri. Kulit batang tanaman jambu mete (Anacardium occidentale Linn.) mengandung senyawa fenolik seperti flavonoid dan tanin serta asam anakardat yang memiliki aktivitas sebagai antibakteri. Salah satu bakteri gram positif dalam mulut yang patogen adalah Staphylococcus aureus (S.aureus). Penelitian ini bertujuan untuk mengetahui aktivitas antibakteri kulit batang jambu mete (anacardium occidentale Linn.) terhadap S.aureus yang ditandai dengan kebocoran ion logam. Penelitian menggunakan sebanyak 1 ose dengan kepadatan $10^{6} \mathrm{CFL} / \mathrm{mL}$ disentrifuse dengan kecepatan $3500 \mathrm{rpm}$ selama 20 menit. Filtrat dibuang, pellet dalam tabung dicuci menggunakan buffer fosfat $\mathrm{pH} 7,0$. Ekstrak etanolik kulit batang jambu mete konsentrasi $3 ; 5$ dan $7 \%$ serta tanpa ekstrak sebagai kontrol, masing-masing dalam 5 tabung, diinkubasi dalam inkubator goyang selama 24 jam. Suspensi kemudian disentrifuse dengan kecepatan 3500 rpm selama 20 menit lalu disaring. Cairan supernatan diambil diukur absorbansinya menggunakan AAS (Atomic absorption Spectroscopy). Data dianalisis menggunakan Anava satu jalur. Hasil menunjukkan kebocoran $\mathrm{Ca}^{2+}$ pada konsentrasi 0, 3, 5 dan 7\% berturut-turut adalah 2,42 $\pm 0,82 ; 32,87 \pm$ 1,$97 ; 49,10 \pm 3,3 ; 66,73 \pm 3,29$, sedangkan logam $\mathrm{K}^{+}$adalah $15,28 \pm 0,46 ; 606,36 \pm 14,14 ; 895 \pm 9,5 ; 1251 \pm 11,54$. Hasil analisis statistik Anava menunjukkan terdapat aktivitas antibakteri ekstrak etanolik kulit batang jambu mete. Hasil LSD menunjukkan terdapat perbedaan yang bermakna antar seluruh kelompok perlakuan. Kesimpulan terdapat aktivitas antibakteri ekstrak etanolik kulit batang jambu mete terhadap S.aureus dilihat dari kebocoran ion logam $\mathrm{Ca}^{2+}$ dan $\mathrm{K}^{+}$. Kebocoran tertinggi pada konsentrasi ekstrak $7 \%$.
\end{abstract}

Kata kunci: aktivitas antibakteri; fenolik; kebocoran ion logam; kulit batang jambu mete (Anacardium occidentale L.)

\begin{abstract}
Antibacterial activity of cashew stembark (Anacardium occidentale Linn) on Staphylococcus aureus. Microbial activity acts as a sign of disruption of bacterial growth. The bark of cashew (Anacardium occidentale Linn.) contains phenolic compounds such as flavonoids, tannins and anacardic acid which have an activity as antimicrobial. One of the Gram positive bacteria in the oral cavity was Staphylococcus aureus (S. aureus). The aim of the study was to observe the bacterial activity of ethanolic extract of the cashew to a metal ion, i.e. $\mathrm{Ca}^{2+}$ and $\mathrm{K}^{+}$leakage from $\mathrm{S}$ aureus. This research used one ose bacteria S. aureus at a density of $10^{6}$ standard Brown as much as $10 \mathrm{~mL}$ and centrifuged at a speed of $3500 \mathrm{rpm}$ for 20 minutes. The filtrate discarded, pellets in the tube was washed using phosphate buffer pH 7.0. Furthermore the ethanolic extract of the bark of the cashew stembark was added in the concentrations of 3.5\% and $7 \%$ without any extract as a control, each of which was in 5 tubes, incubated in an incubator for 24 hours. The suspension was centrifused with a speed of $3500 \mathrm{rpm}$ for 20 minutes prior to be filtered. Supernatant liquid was taken and measured absorbance using AAS. Data were analyzed using one way Anova $p=0.05$. The results showed that leakage of $\mathrm{Ca}^{2+}$ was at concentrations of $0 \%, 3 \%, 5 \%$ and $7 \%$ were $2.42 \pm 0.82 ; 32.87 \pm 1.97 ; 49.10 \pm 3.33 ; 66.73 \pm 3.29$, respectively while for the $K^{+}$metal was $15.28 \pm 0.46 ; 606.36 \pm 14.14 ; 895 \pm 9.5 ; 1251 \pm 11.54$. Anova one way showed a significant effect $(p<0.050)$ ethanolic extract of the bark of cashew against leakage of metal ions $\mathrm{Ca}^{2+}$ and $\mathrm{K}^{+}$at $S$ aureus bacteria. LSD test showed a significant difference among all treatment groups. It was concluded that there was antibacterial activity of ethanolic extract of the cashew stembark on bacteria S. aureus based on leakage of metal ions $\mathrm{Ca}^{2+}$ and $\mathrm{K}^{+}$. The highest leakage of metal ions was at the concentrations of $7 \%$.
\end{abstract}

Keywords: antimicrobial activity; phenolic; metal ion leakage; cashew steambark (Anacardium occidentale L)

\section{PENDAHULUAN}

Jambu mete mempunyai nama latin Anacardium occidentale Linn, merupakan salah satu komoditas yang banyak manfaatnya mulai dari akar, batang, daun dan serta buahnya. ${ }^{1}$ Penelitian tentang kandungan kulit batang jambu mete dengan ekstraksi etanol menunjukkan bahwa kulit batang jambu mete mengandung senyawa kimia fenolik seperti asam anakardat, asam galat, flavonoid serta saponin yang bermanfaat sebagai antibakteri. ${ }^{2,3}$ 
Salah satu jenis bakteri Gram (+) dalam rongga mulut adalah Staphylococcus aureus (S.aureus) yang merupakan bakteri aerob, berbentuk bulat atau lonjong (0,8 sampai 0,9 $\mu \mathrm{m})$, tidak bergerak, tidak bersimpai, tidak berspora dan bersifat patogen. ${ }^{4}$ Bakteri Gram (+) tersusun atas lapisan yang relatif tebal terdiri dari lipopolisakarida dan lapisan peptidoglikan. ${ }^{5}$

Interaksi senyawa antibakteri dapat menyebabkan kerusakan dinding sel dan menyebabkan bakteri mengalami kematian. Derajad kerusakan dinding sel dapat diukur dengan jumlah $\mathrm{Ca}^{2+}$ dan $\mathrm{K}^{+}$yang keluar dari sel bakteri. Kerusakan dinding sel bakteri telah diamati oleh peneliti terdahulu, diantaranya menguji aktivitas antibakteri daun dan umbi Crinum asiaticum Ldan monoasil gliserol minyak kelapa, daun sirih dan temu kunci (kaempheria pandurata). ${ }^{6,7,8,9}$ Penelitian ini bertujuan untuk mengetahui mekanisme kerja antibakteri kulit batang jambu mete dengan berbagai konsentrasi terhadap $S$.aureus dengan mengukur jumlah $\mathrm{Ca}^{2+}$ dan $\mathrm{K}^{+}$menggunakan $A A S$ (Atomic Absorption Spectroscopy) Perkin Elmer.

\section{METODE PENELITIAN}

\section{Bahan dan Alat}

Kulit batang jambu mete diperoleh dari pohon jambu mete perkebunan jambu mete di Mojolegi, Karang tengah Imogiri, Bantul. Usia pohon sekitar 5 tahun. dan kulit batang diambil sekitar $1 \mathrm{~m}$ dari tanah, melingkar dengan lebar $5 \mathrm{~cm}$. Ekstraksi kulit batang jambu mete dilakukan di Laboratorium Biologi Farmasi Fakultas Farmasi, Universitas Gadjah Mada. Metode yang digunakan adalah maserasi menggunakan pelarut etanol $70 \%$. Pelarut etanol dipilih karena pelarut ini dapat menarik senyawa aktif dari kulit batang jambu mete, etanol memiliki gugus hidroksil yang dapat membentuk ikatan hidrogen dengan senyawa fenolik. Setelah diperoleh ekstrak kental kemudian dibuat konsentrasi 3\%, $5 \%$ dan $7 \%$ dalam pelarut air suling. Analisis kebocoran ion logam bakteri $S$ aureus dilakukan di Laboratorium Analitik Fakultas MIPA UGM. Prosedur penelitian telah direview oleh Komisi Etik Penelitian FKG UGM dengan nomor: 308/ KKEP/FKG-UGM/EL/2012

\section{Pembuatan suspensi S.aureus}

S. aureus sebanyak 1 ose dari stok agar miring diinokulasikan ke dalam media nutrient broth (NB) dan diinkubasi selama 24 jam pada suhu 37 ${ }^{\circ} \mathrm{C}$. Sebanyak $1 \mathrm{~mL}$ kultur bakteri ditambahkan ke dalam $9 \mathrm{~mL}$ media NB dan diinkubasi selama 24 jam pada suhu $37^{\circ} \mathrm{C}$. Kultur bakteri uji yang digunakan untuk menentukan kebocoran ion logam $\mathrm{Ca}^{2+}$ dan $\mathrm{K}^{+}$dibuat $10^{6} \mathrm{CFU} / \mathrm{mL}$.

\section{Analisis Kebocoran Ion Logam}

Analisis kebocoran ion yang diukur adalah $\mathrm{K}^{+}$ dan $\mathrm{Ca}^{2+}$ yang keluar dari sel S.aureus akibat perlakuan ekstrak etanolik kulit batang jambu mete. Suspensi bakteri yang telah ditumbuhkan selama 24 jam dalam NB diambil sebanyak 10 $\mathrm{mL}$ dan dilakukan sentrifuge dengan kecepatan 3500 rpm selama 20 menit. Filtrat dibuang, pellet dalam tabung dicuci menggunakan buffer fosfat $\mathrm{pH} 7,0$. Selanjutnya ditambahkan ekstrak etanolik kulit batang jambu mete dengan konsentrasi $3 \%$, $5 \%$ dan $7 \%$ serta tanpa ekstrak sebagai kontrol, masing-masing dalam 5 tabung. Selanjutnya diinkubasi dalam inkubator goyang selama 24 jam. Suspensi dilakukan sentrifuge dengan kecepatan 3500 rpm selama 20 menit lalu disaring. Cairan supernatan diambil dan diukur absorbansinya menggunakan AAS.

\section{HASIL PENELITIAN}

Hasil penelitian tentang aktivitas anti bakteri ekstrak kulit batang jambu mete dengan mengukur kebocoran ion logam $\mathrm{K}^{+}$dan $\mathrm{Ca}^{2+}$ pada S.aureus menunjukkan terdapat kecenderungan naiknya kebocoran ion seiring dengan kenaikan konsentrasi ekstrak. Hasil uji Anava untuk $\mathrm{Ca}^{2+}$ maupun ion $\mathrm{K}^{+}$menunjukkan terdapat pengaruh ekstrak etanolik kulit batang jambu mete yang bermakna $(p<0,05)$ terhadap kebocoran ion logam $\mathrm{Ca}^{2+}$ dan $\mathrm{K}^{+}$. 


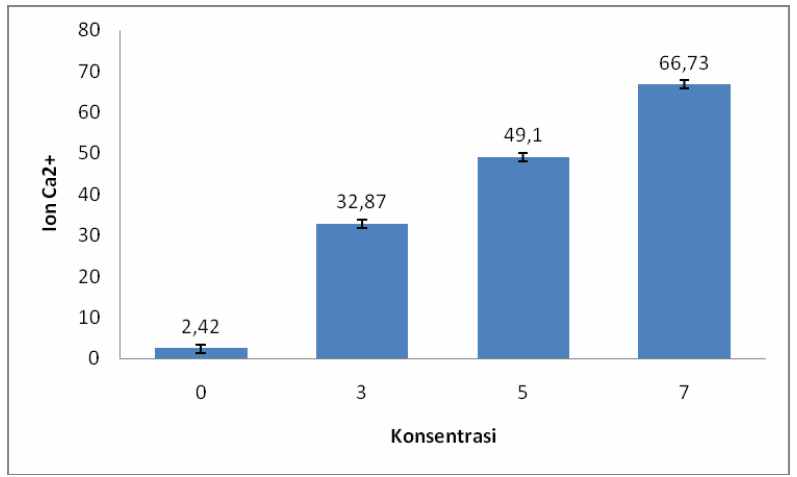

Gambar 1. Grafik kebocoran ion logam $\mathrm{Ca}^{2}+$ dari bakteri $S$ aureus setelah dikontakkan dengan ekstrak etanolik kulit batang jambu mete konsentrasi 0, 3, 5 dan 7\%

Gambar 1 terlihat adanya kenaikkan kebocoran $\mathrm{Ca}^{2+}$ seiring dengan kenaikkan konsentrasi ekstrak etanolik kulit batang jambu mete. Nilai kebocoran $\mathrm{Ca}^{2+}$ terendah ada pada kelompok kontrol.

Tabel 1. Uji Anava kebocoran $\mathrm{Ca}^{2+}$ pada bakteri S.aureus

\begin{tabular}{lrcccc}
\hline Jumlah kuadart & $\begin{array}{c}\text { Jumlah } \\
\text { kuadrat }\end{array}$ & $\begin{array}{c}\text { Derajad } \\
\text { bebas }\end{array}$ & Rerata & $\begin{array}{c}\text { Nilai } \\
\text { F }\end{array}$ & $\begin{array}{l}\text { Proba- } \\
\text { bilitas }\end{array}$ \\
\hline Antar kelompok & 11096,390 & 3 & 3698,797 & 6,637 & 0.0001 \\
Dalam Kelompok & 106,185 & 16 & & & \\
Total & 11202,574 & 16 & & & \\
\hline
\end{tabular}

Nilai $p<0,05=$ terdapat perbedaan bermakna

Hasil uji Anava menunjukkan nilai $\mathrm{F}$ sebesar 6,637 dengan nilai signifikansi 0,0001 yang berarti $<0,05$. Terdapat pengaruh yang bermakna konsentrasi ekstrak etanolik kulit batang jambu mete terhadap kebocoran ion logam $\mathrm{Ca}^{2+}$.

Tabel 2. Uji LSD kebocoran $\mathrm{Ca}^{2+}$ pada bakteri S aureus

\begin{tabular}{ll}
\hline Kelompok Uji & Hasil perbedaan \\
\hline $0-3 \%$ & $30,37^{*}$ \\
$0-5 \%$ & $46,60^{*}$ \\
$0-7 \%$ & $63,95^{*}$ \\
$3-5 \%$ & $16,23^{*}$ \\
$3-7 \%$ & $33,58^{*}$ \\
$5-7 \%$ & $17,35^{*}$ \\
\hline
\end{tabular}

*= terdapat perbedaan yang bermakna

Hasil uji LSD menunjukkan perbedaan yang bermakna $(p<0,05)$ antar semua kelompok perlakuan ekstrak kulit batang jambu mete konsentrasi $3 \%$, $5 \%$, dan $7 \%$ serta kelompok kontrol.

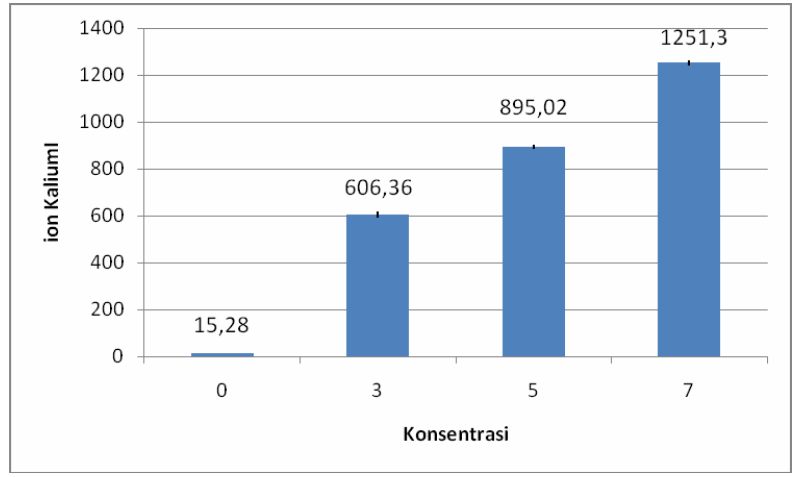

Gambar 2. Grafik kebocoran ion logam $\mathrm{K}^{+}$dari $S$ aureus setelah dikontakkan dengan ekstrak etanolik kulit batang jambu mete konsentrasi 0, 3, 5 dan $7 \%$

Gambar 2 terlihat adanya kenaikkan kebocoran $\mathrm{K}^{+}$seiring dengan kenaikkan konsentrasi ekstrak etanolik kulit batang jambu mete. Seperti hal nya dengan $\mathrm{Ca}^{2+}$, kebocoran ion $\mathrm{K}^{+}$terendah pada kelompok kontrol. Hasil uji Anava menunjukkan terdapat pengaruh yang bermakna konsentrasi ekstrak etanolik kulit batang jambu mete terhadap kebocoran ion logam $\mathrm{K}^{+}(\mathrm{p}<0,05)$. Hasil uji LSD menunjukkan terdapat perbedaan antar semua kelompok perlakuan yang bermakna.

Tabel 3. Uji Anava kebocoran $\mathrm{K}^{+}$dari bakteri S aureus

\begin{tabular}{lccccc}
\hline Jumlah kuadrat & $\begin{array}{c}\text { Jumlah } \\
\text { kuadrat }\end{array}$ & $\mathrm{Db}$ & $\begin{array}{c}\text { Rerata } \\
\text { kuadrat }\end{array}$ & Nilai F & $\mathrm{p}$ \\
\hline Antar kelompok & $\begin{array}{c}4096612,97 \\
\text { Dalam Kelompok }\end{array}$ & $\begin{array}{c}106,185 \\
16\end{array}$ & 1365537,66 & 2573,00 & 0,0001 \\
Total & 11202,574 & 16 & & & \\
\hline
\end{tabular}

Nilai $p<0,05=$ terdapat perbedaan bermakna

Tabel 4. Uji LSD kebocoran ion logam $\mathrm{K}^{+}$pada bakteri $\mathrm{S}$ aureus

\begin{tabular}{cc}
\hline Kelompok Uji & Hasil perbedaan \\
\hline $0-3 \%$ & $591,07^{*}$ \\
$0-5 \%$ & $879,74^{*}$ \\
$0-7 \%$ & $1236,03^{*}$ \\
$3-5 \%$ & $288,66^{*}$ \\
$3-7 \%$ & $644,94^{*}$ \\
$5-7 \%$ & $356,28^{*}$ \\
\hline
\end{tabular}

*= terdapat perbedaan yang bermakna

\section{PEMBAHASAN}

Hasil uji aktivitas antibakteri menunjukkan bahwa ekstrak etanolik kulit batang jambu mete mampu 
menghambat pertumbuhan bakteri S. aureus karena mengandung senyawa aktif flavonoid, saponin, tanin yang dapat sebagai antibakteri. ${ }^{3}$ Pemberian ekstrak etanolik kulit batang jambu mete diduga dapat menyebabkan kebocoran sel yang berakibat pada kematian S.aureus. Kebocoran ion akibat rusaknya dinding sel dapat dideteksi dengan AAS. ${ }^{10}$

Pemberian ekstrak etanolik kulit batang jambu mete pada konsentrasi $3 \%, 5 \%$ dan $7 \%$ dapat mengakibatkan keluarnya ion logam dari sel bakteri, antara lain ion kalium dan kalsium. Ion $\mathrm{K}^{+}$pada bakteri yang berperan penting dalam fungsi dan kesatuan ribosom, sedangkan $\mathrm{Ca}^{2+}$ dibutuhkan sebagai komponen dinding sel bakteri gram positif. ${ }^{11}$ Menurut Suliantari (2009) $\mathrm{Ca}^{2+}$ berfungsi untuk menjaga kestabilan dinding bakteri dan dengan adanya keluarnya ion tersebut dari sel maka kestabilan dinding sel akan terganggu yang selanjutnya dapat mengakibatkan kematian bakteri. ${ }^{8,12}$

Kebocoran ion pada konsentrasi $7 \%$ ekstrak etanolik kulit batang jambu mete relatif lebih banyak dibandingkan pada kelompok lainnya. Hal ini dapat diterangkan apabila makin banyak atom $\mathrm{O}$ dari senyawa fenolik berikatan dengan atom $\mathrm{H}$ pada protein bakteri, maka struktur protein baik pada dinding sel maupun membran sel bakteri mengalami perubahan. Hal ini juga sejalan dengan penelitian Mokhtar dkk., bahwa, kenaikkan konsentrasi fenolik akan mempertinggi efek antibakterial, bahwa semakin tinggi konsentrasi suatu bahan antibakteri dan semakin lama kontak maka aktivitas antibakterinya semakin kuat pula. ${ }^{13}$ Konsentrasi ekstrak yang semakin tinggi maka semakin tinggi pula kandungan senyawa fenol ataupun zat antibakterinya, ${ }^{14}$ semakin banyak ion logam yang keluar dari sel bakteri

\section{KESIMPULAN}

Terdapat aktivitas antibakteri ekstrak etanolik kulit batang jambu mete terhadap $S$ aureus yang ditandai dengan kebocoran ion logam $\mathrm{Ca}^{2+}$ dan $\mathrm{K}^{+}$. Jumlah ion yang dilepaskan dipengaruhi oleh konsentrasi ekstrak kulit batang jamu mete.

\section{DAFTAR PUSTAKA}

1. Aderiye BI, David OM, Atere VA. Administration of cashew extracts in the treatment of some infections and diseases. J Adv Med Plant Res. 2015; 3(3): 75 - 86 .

2. Abulude FO, Ogukoya MO, Akinjagunla YS. Phytochemical screening of leaves and stem of Cashew tree (Anacardium occidentale). EJEAF. 2010; 9(4): 815 - 819.

3. Harsini H. Pengaruh ekstrak etanolik kulit batangb jambu mete (Anacardium Occidentale Linn.) dalam obat kumur terhadap pertumbuhan S. aureus. Majalah Kedokteran Gigi Indonesia. 2009; 16(1): 13 - 16.

4. Kayser. Color atlas of medicinal microbiology. Germany; 2005. 3, 5, 152, 229 - 304.

5. Tortora GJ, Funke BR, Case CC. Microbiology: an introduction $10^{\text {th }}$ ed. London: Pearson; 2010. 186-188.

6. Azifiria SA, Chairul. Aktivitas antibakteri ekstrak etanolik daun dan umbi Crinum asiaticum L. terhadap bakteri penyebab jerawat. Majalah Farmasi Indonesia. 2010; 21(4): 236 - 241.

7. Asriani, Laksmi BS, Yasin S, Sudirman I. Mekanisme antibakteri metabolit Lb Plantarium kik dan monoasil gliserol minyak kelapa terhadap bakteri pathogen pangan. J Teknol pangan. 2007; 18(2): 126 - 133.

8. Sabrina, Musdja MY, Pratiwi L. Uji aktivitas mekanisme penghambatan minyak atisiri daun sirih (Piper bettle Linn) dan ekstrak etanol daun sirih terhadap beberapa bakteri Gram (+). Farmasains. 2011; 1(3): 117 - 122.

9. Miksusanti, Jenie BSL, Syarief R, Pontjo B, Mulyadi GT. Antibacterial activity of temu kunci tuber (kaempheria pandurata) essential oil againt Bacillus cereus. Med. J Indones. 2009; 18(1): $10-17$.

10. Park SJ, Park HW, Park J. Inactivation kinetics of food poisoning microorganism by carbon deocide and high hydrostatic pressure. $\mathrm{J}$ food Sci. 2003; 68(3): 976 - 981. 
11. Nikaido $H$, Vaara $M$. Molecular basis of bacterial outer membrane permiability. Microbiological reviews. 1985; 49(1): 1 - 32.

12. Suliantari, Jenie, Maggy T, Suhartono. Aktivitas antibakteri dan mekanisme penghambatan ekstrak Sirih Hijau (Piper betle Linn) terhadap bakteri patogen pangan. J Teknol dan Industri Pangan. 2012; 23(2): $217-220$.
13. Mokhtar NM, Kanthimathi, Aziz AA. Comparisons between the antioxidant activities of the extracts of Anacardium occidentale and piper betle. Malaysian $\mathrm{J}$ of Biochem and Mol Biology. 2008; 16(1): 16 - 24.

14. Mustapha $Y$, Hafsat S. Antibacterial activities of Anacardium Occidentale. International Journal of Pure and Applied Sciences (IJPAS). 2007; 1(1): $40-43$. 